\title{
Historical and modern landscape forest structure in fir (Abies)-dominated mixed conifer forests in the northern Sierra Nevada, USA
}

Scott L Stephens ${ }^{1 *}$, Jens T Stevens ${ }^{1}$, Brandon M Collins ${ }^{2}$, Robert A York ${ }^{1}$ and Jamie M Lydersen ${ }^{1}$

\begin{abstract}
Background: Information about fire and historical forest structure and composition in fir-dominated mixed conifer forests is lacking, especially at the landscape scale. This study used historical timber survey data to characterize early forest conditions in a large fir-dominated northern Sierra Nevada landscape (area >10 000 ha). We used automated model selection to determine the suite of environmental variables that best predicted forest structure, and regression tree analysis to identify environmental settings associated with historical forest conditions and to provide a comparison to contemporary forest data.

Results: While changes at our study site were more subtle when compared to those in more xeric, pine-dominated mixed conifer areas in the central and southern Sierra Nevada, there were significant increases in small-tree density and a decrease in large-tree density in the current forest. The loss of large trees was most pronounced in environments with relatively low summer water deficit and shallow slopes, which is where the highest large-tree densities were observed historically. Within the historical forest, tree density and basal area were greater in areas with higher precipitation and actual evapotranspiration, along with lower snowpack.

Conclusions: Our results indicated that restoration plans should differ depending on the type of mixed conifer forest encountered. Whereas low tree densities and basal areas produced open stand conditions in many pine-dominated regions of this forest type, areas that were dominated by fir species with longer growing seasons, high water availability, and low water demand were denser and likely provided important habit for late seral species such as the California spotted owl, Strix occidentalis occidentalis (Xántus de Vesey, 1860). Working to develop forest restoration and adaptation plans to account for these differences is an important strategy to restore resiliency and encourage adaption in fire-excluded mixed conifer forests.
\end{abstract}

Keywords: Abies concolor, adaption, forest management, historical range of variability, reference conditions, restoration, white fir

\footnotetext{
* Correspondence: sstephens@berkeley.edu

${ }^{1}$ Department of Environmental Science, Policy, and Management, Ecosystem

Sciences Division, University of California, 130 Mulford Hall, Berkeley,

California 94720-3114, USA

Full list of author information is available at the end of the article
} 


\section{Resumen}

Antecedentes: Información sobre incendios, estructura histórica y composición en bosques mixtos de coníferas dominados por abetos es inexistente, especialmente a escala de paisaje. Este estudio utilizó datos históricos de relevamientos madereros para caracterizar las condiciones iniciales de un gran bosque dominado por abetos en el norte de Sierra Nevada (superficie >10.000 ha). Utilizamos para ello un modelo de selección automático para determinar la serie de variables ambientales que mejor predijeran la estructura del bosque, y análisis de regresión de árboles para identificar ajustes ambientales asociados a condiciones históricas del bosque y para proveer una comparación con datos del bosque contemporáneo.

Resultados: Mientras que los cambios en nuestro sitio de estudio fueron más sutiles que cuando fueron comparados con áreas de sitios más xéricos dominados por bosques mixtos de pino y coníferas en el centro y sur de Sierra Nevada, hubo incrementos significativos en la densidad de árboles pequeños y disminuciones en la densidad de árboles grandes en el bosque en estudio. La pérdida de árboles grandes fue más pronunciada en ambientes con relativamente bajo déficit de agua en verano y pendientes poco profundas, que es donde históricamente se observaron las mayores densidades de árboles grandes. Dentro del bosque histórico, la densidad de árboles y el área basal fueron mayores en áreas con mayor precipitación y evapotranspiración, y que a la vez presentaron un colchón de nieve más reducido.

Conclusiones: Nuestros resultados indicaron que los planes de restauración deberían diferenciarse dependiendo del tipo de bosque mixto de conífera de que se trate. Mientras que densidades y áreas basales bajas produjeron condiciones de rodales abiertos en numerosos regiones dominadas por pino en este tipo de bosque, áreas dominadas por especies de abeto con estaciones de crecimiento más largas, gran disponibilidad de agua, y una demanda de agua baja fueron más densos y probablemente proveyeron un hábitat importante para especies serales tardías como la lechuza moteada de California, Strix occidentalis occidentalis (Xántus de Vesey, 1860). El trabajo para desarrollar la restauración de bosques y planes de adaptación que tengan en cuenta estas diferencias es una estrategia importante para restaurar la resiliencia y estimular la adaptación en bosques mixtos de coníferas donde el fuego ha sido excluido.

\section{Background}

In the western Sierra Nevada, as elevation and moisture availability increase, there is a gradual transition from ponderosa pine (Pinus ponderosa Lawson \& C. Lawson) forests, through mixed conifer (MC), to more or less pure white fir (Abies concolor [Gordon \& Glend.] Lindl.), and finally to red fir (Abies magnifica A. Murray bis) forests (Vankat and Major 1978; Conard and Radosevich 1982). These diverse forests were first used by Native Americans and later by Euro-American immigrants who initiated extensive mining, logging, grazing, fire suppression, and urban expansion (Beesley 1996). According to Barbour et al. (1993), roughly half of the area of the MC forest in the Sierra Nevada was logged at least once over the last 150 years, highlighting the magnitude of anthropogenic derived change in this region.

Overall tree density (especially small- to medium-sized shade-tolerant trees) has increased in many areas in the Sierra Nevada from fire suppression (e.g., Vankat and Major 1978; Parsons and Debendetti 1979; Beaty and Taylor 2008; Dolanc et al. 2014a, 2014b; Levine et al. 2017; Easterday et al. 2018), leading to an expansion of $\mathrm{MC}$ forests at the expense of ponderosa pine forests in this mountain range (Dolanc et al. 2014a; Safford and Stevens 2017). Higher small-tree densities and greater surface fuel loads have increased fire hazards in many Sierra Nevada forests, especially those that once burned frequently with low-moderate intensity fire regimes (Biswell 1989; Agee and Skinner 2005; Stephens et al. 2009).

While past management and climate change are modifying disturbance regimes to create novel conditions, information from historical or reference conditions is still essential to managers and scientists (Millar et al. 2007, Stephens et al. 2010). Recently, historical forest reconstructions at the landscape scale that have relied on direct measurements have been done to improve the understanding of pre fire-suppression structure for ponderosa pine forests in the southern Sierra Nevada (Stephens et al. 2015) and for pine-dominated MC forests in the central and southern Sierra Nevada (Collins et al. 2015, 2017; Stephens et al. 2015). Other reconstructions based on General Land Office Survey data have been done in Sierra Nevada MC forests (Baker 2014), but they have been shown to overestimate past forest density (Levine et al. 2017; Hagmann et al. 2018). Very little historical forest structure information exists for fir-dominated forests in the Sierra Nevada at the landscape scale. Indeed, there is a need for more broad-scale analysis of structural change in forests across much of the Sierra Nevada, across land ownership boundaries, and across the elevational distribution of individual species (Dolanc et al. 2014b). Because of the stark climatic gradients in this region, historical forest 
structure likely varied along these gradients even with a frequent fire regime (Safford and Stevens 2017), but this variation in historical structure has been poorly quantified at the more mesic, higher-elevation ends of these gradients.

True fir forests have more complex fire regimes when compared to more xeric ponderosa pine, Jeffrey pine (Pinus jeffreyi Balf.), and pine-dominated MC forests (Perry et al. 2011; Hessburg et al. 2016). True fir forests experienced highly variable historical fire regimes, exhibiting a range in both fire frequencies and stand-replacing patch sizes (Taylor and Halpern 1991; Taylor and Solem 2001; Meyer and North 2018). Montane chaparral can rapidly colonize larger patches of stand-replacing fire in true fir forests. However, in the absence of fire, these patches can eventually become dominated by conifers (mainly white and red fir) as trees become established and ultimately overtop shrubs (Conard and Radosevich 1982).

Historical forest and fire dynamics in the transition from MC to true fir forests have been studied in the southern Cascades (Taylor and Halpern 1991; Beaty and Taylor 2001; Taylor and Solem 2001), but comparable information from the Sierra Nevada is lacking. To address this need, we characterized historical forest conditions and assessed compositional and structural change in the contemporary period. We also used quantitative analysis to identify the factors driving historical forest structure and composition. By comparing current forest conditions to those based on direct measurements from early inventories, we provide information on if or how potential changes in these forests differ from those in pine-dominated MC forests. Such a comparison can provide information to managers on how consistent forest restoration strategies may be between the two forest types. A differing historical structure in fir-dominated MC forests would suggest different restoration approaches for managers. Our specific objectives were to: (1) summarize historical timber inventory records, (2) identify distinct environmental factors associated with these forest types, and (3) compare past and current forest conditions for fir-dominated $\mathrm{MC}$ forests at the landscape scale in the northern Sierra Nevada. Information from this study could be useful to managers interested in forest restoration and adaption and to scientists who model forest dynamics in the Sierra Nevada.

\section{Methods}

\section{Study area management and fire history}

Historical data was collected on two sites located on the El Dorado National Forest in northern California, USA (Fig. 1). Livestock grazing and mining homesteads occurred near the study areas in the late 1800s. Logging in pine-dominated $\mathrm{MC}$ forests occurred at elevations below the northern study site (Fig. 1), with railroad logging between 1896 and 1920 (Polkinghorn 1984). The University of California Blodgett Forest, which is approximately $10 \mathrm{~km}$ west of the northern study site, was logged between 1900 and 1915 by Michigan California Lumber Company. This early logging focused on lower-elevation, easily accessible forests first, eventually logging up to approximately $1500 \mathrm{~m}$.

While there is no published fire history from either study area, the northern site is approximately $10 \mathrm{~km}$ from where Stephens and Collins (2004) worked in pine-dominated MC forests. Between 1750 and 1900, median composite fire interval at the 9 to 15 ha spatial scale was 4.7 years, with a fire interval range of 4 to 28 years (Stephens and Collins 2004). This study also reported a large range in the year of the latest recorded fire (from 1838 to 1921), which varied across focused fire scar collection areas throughout the studied forest. The 1921 fire year was recorded in the least accessible area (north of Pilot Creek), which is only $5 \mathrm{~km}$ west of our northern study area. While lower, more accessible areas had the last recorded fire in 1838 (near an early homestead settlement and the Bacchi Barn), more remote areas still experienced fires into the early twentieth century (Stephens and Collins 2004).

\section{Historical data source}

The historical forest structure data came from the US Forest Service's Region 5 (California) timber inventory program, which surveyed lands under federal ownership to assess timber stocks prior to harvesting in the early 1900s. Timber survey methods varied by national forest within Region 5, but all timber surveys in this period adopted a belt transect approach, with transects from $20.1 \mathrm{~m}$ (1 chain, $66 \mathrm{ft}$ ) to $40.2 \mathrm{~m}$ in width, and $402.3 \mathrm{~m}$ (20 chains, $1320 \mathrm{ft}$ ) in length, spanning the length of one 16.2 ha (40 acre) quarter-quarter section. On the El Dorado National Forest (ENF), the majority of transects were $20.1 \mathrm{~m}$ wide by $402.3 \mathrm{~m}$ long, and a majority of quarter-quarter sections had two transects within them (i.e., 10\% sample intensity). For the specific area for which we have historical data, the surveyors sampled two townships (Fig. 1); the southern township (T10) was sampled in 1923 and the northern township (T13) was sampled in 1936. Based on similar timber surveys conducted around this time period, transects were surveyed by two- to three-person crews, with approximately eight transects surveyed per day (Hagmann et al. 2018). Independent efforts to evaluate the accuracy of these timber surveys, called "check cruises," revealed that tree densities were within $-6 \%$ to $+19 \%$ of the check cruise densities, with no systematic tendency for over- or under-estimation (Hagmann et al. 2018).

\section{Data processing}

For instances in which there were multiple transects for a given quarter-quarter section, the historical timber survey data were pooled to the quarter-quarter section scale (16.2 ha). Density data covered all trees $>15.2 \mathrm{~cm}$ (6 in.) in diameter at breast height $(\mathrm{DBH})$, with size class 

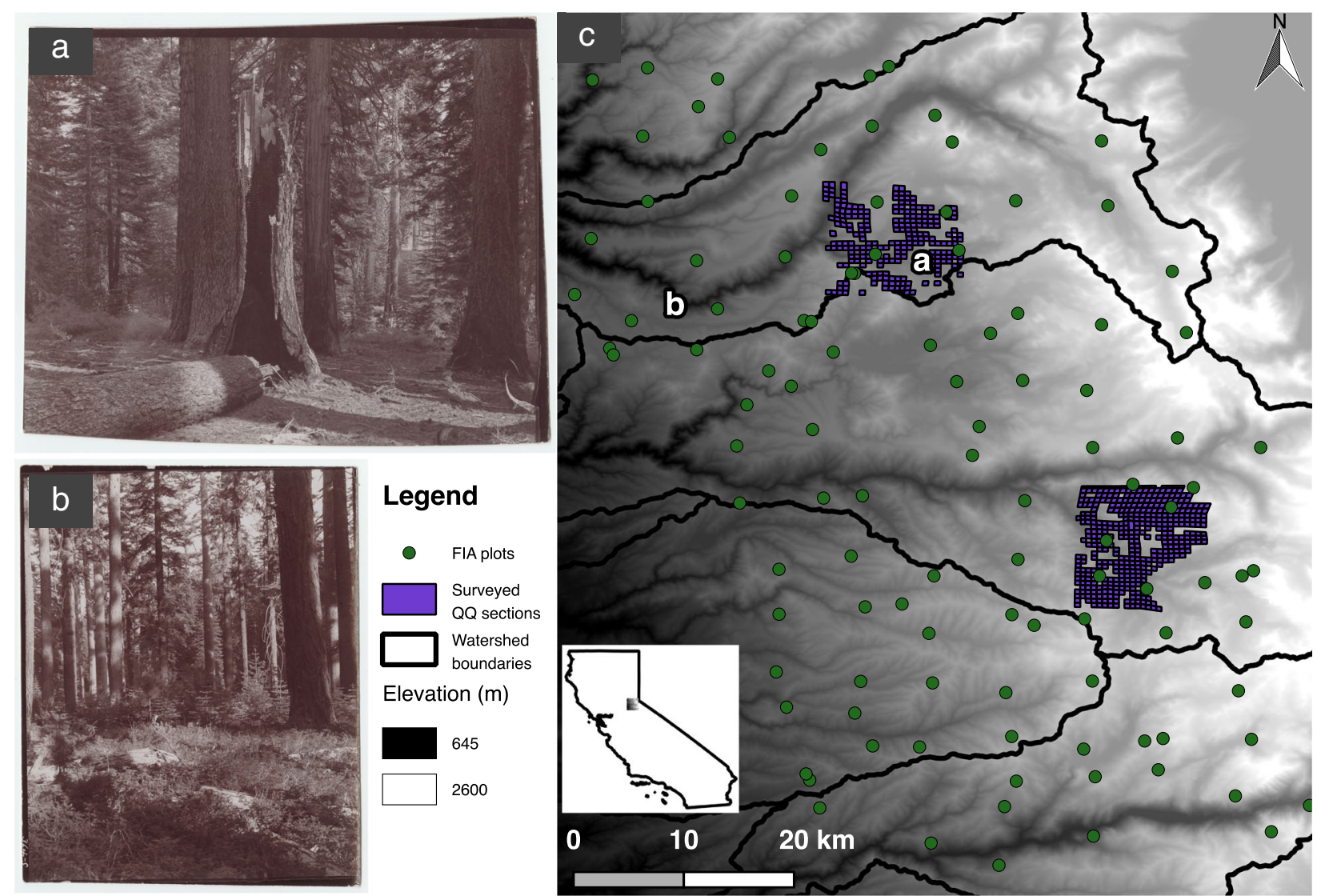

Fig. 1 Study area (c) showing approximate locations for photo points (a and $\mathbf{b}$; Sudworth 1899); timber surveys from quarter-quarter (QQ) sections (purple squares) surveyed in 1923 (southern township) and 1936 (northern township), and modern FIA plots (green points) from 2001 to 2010. Inset figure in (c) shows location of study area. Elevation shown in grayscale in (c) ranges from $645 \mathrm{~m}$ to $2600 \mathrm{~m}$. Watershed boundaries (black lines) indicate, from north to south, the Middle Fork American River, Rubicon River, South Fork American River, Consumnes River, and Mokelumne River watersheds, all flowing west from the Sierra Nevada crest

breakpoints set at $30.5 \mathrm{~cm}$ (12 in.) DBH, $61.0 \mathrm{~cm}(24$ in.) $\mathrm{DBH}$, and $91.4 \mathrm{~cm}(36$ in.) DBH. Basal area data included all trees $>15.2 \mathrm{~cm} \mathrm{DBH}$ and were specified by species but not by size class. Prior to filtering out non-forested plots, our sample size in the historical dataset was 642 individual quarter-quarter sections. To be consistent in our comparisons to the modern Forest Inventory and Analysis (FIA) data, we removed quarter-quarter sections from our analysis when basal area was below $9 \mathrm{~m}^{2} \mathrm{ha}^{-1}(n=19)$, including three sections that lacked any live trees, for a final study area of 623 individual quarter-quarter sections that covered 10093 ha.

Modern FIA data were selected for comparison to historical data by filtering all plots sampled within the footprint of the ENF (258 plots total) according to a set of criteria described below (final $n=91$ ). We only included data from the 2001 to 2010 sampling interval $(n=176)$, thereby excluding plots that were sampled a second time after 2010 on a re-measurement cycle. This sampling interval from 2001 to 2010 was used because it had a consistent protocol, and true plot coordinates were generally within $0.8 \mathrm{~km}$
(0.5 mi.) of the reported location (Woudenberg et al. 2010; distances were greater in earlier plots sampled during the 1990s that were excluded from the analysis). Within this sampling interval, we filtered the FIA data to only include plots within the elevation range of the historical timber survey data (1229 to $2438 \mathrm{~m} ; n=117)$. We then removed non-forested plots when the reported basal area was below $9 \mathrm{~m}^{2} \mathrm{ha}^{-1}(n=21)$. This threshold excluded plots that were non-stocked and likely recently harvested $(n=8)$, young stands with a stand age of $<25 \mathrm{yr}$ that were likely plantations $(n=8)$, plots with substantial insect damage $(n=2)$, and one plot with no clear reason for a low basal area. Of the remaining 98 plots, we removed plots with fire damage in the disturbance code field $(n=3)$ and plots with a subalpine forest type ( $n=1$; mountain hemlock, Tsuga mertensiana [Bong.] Carrière, forest type). Finally, we removed plots where the "fuzzing" of public coordinates placed the plot coordinates at a markedly different elevation than the reported elevation in the FIA database. We used $150 \mathrm{~m}$ of elevation discrepancy between the FIA reported value and the value 
determined by the plot coordinates as a breakpoint, and removed three plots that had more than $150 \mathrm{~m}$ in elevation discrepancy.

The final FIA dataset for comparison analysis included 91 plots. Of these, 42 sampled more than one "condition," indicating that portions of the plot had different predominant ages, predominant species, or disturbance histories (Woudenberg et al. 2010). Furthermore, 19 plots were at least partially on private land, with 72 plots entirely on public land. As our objective was to illustrate changes in current conditions within the same geographic region as the historical data, and given that the original timber survey transects spanned multiple forest conditions and aggregated that structure data to the transect level (Hagmann et al. 2018), we included these multiple-condition plots in our analyses.

Because the historical timber surveys sampled forest structure during two separate years (1923 and 1936), the absence of fire in this 16-year period likely allowed for additional tree recruitment into the smallest size classes in the 1936 dataset (Lydersen et al. 2013). A simple linear model of density conditional on sample year showed a significant increase from 1923 to $1936(t=7.6, P<0.001)$, but a comparable model of basal area showed no significant difference between the years $(t=-1.3, P=0.19)$. This increase in tree density was observed only in the 15.2 to $30.5 \mathrm{~cm}$ (6 to $12 \mathrm{in}$.) DBH size class and, to a lesser extent, in the 30.5 to $45.7 \mathrm{~cm}$ (12 to $18 \mathrm{in}$.) $\mathrm{DBH}$ size class (Additional file 1: Figure S1), again suggesting recruitment during fire suppression as the mechanism. To correct for this, we calculated the ratio of trees in each of these size classes in 1923 versus 1936, and multiplied this correction factor by the density of trees within each of these size classes at each transect sampled in 1936 to estimate the corrected density for these transects in 1923 . The correction factors were 0.40 for the 15.2 to $30.5 \mathrm{~cm}$ DBH size class, and 0.69 for the 30.5 to $45.7 \mathrm{~cm}$ DBH size class. Hereafter, we refer to the historical timber surveys as reflecting 1923 conditions since the two townships have similar species composition, basal area, and large-tree density, while acknowledging that there could be some site differences that are not fully accounted for in this work.

For each timber survey transect (1923) or FIA plot (2001 to 2010), we extracted the underlying topographic and climatic variables from $10 \mathrm{~m}$ (topographic) to $270 \mathrm{~m}$ (climatic) resolution rasters, averaging values from multiple pixels to a single quarter-quarter section from the 1923 surveys when data from multiple transects had been pooled. Topographic data came from the National Map (https://www.usgs.gov/core-science-systems/ngp/tnm-deli very/) and climatic data came from the California Climate Commons (http://climate.calcommons.org/node/1129) using the Basin Characterization Model (Flint et al. 2013). We specifically included the topographic variables of elevation and slope, and a categorical slope-aspect variable (with breakpoints at $135^{\circ}$ and $315^{\circ}$ ) to distinguish northeastfacing and southwest-facing aspects. We included the climatic variables of mean annual climatic water deficit, mean June climatic water deficit, actual evapotranspiration, mean 1 April snowpack, mean annual precipitation, and mean annual high temperature. Climatic data were 30-year mean values from 1981 to 2010.

\section{Data analysis}

We used automated model selection to determine the suite of environmental variables that best predicted variation in tree density, basal area, and fir-pine ratio (FPR: calculated as the basal area of fir divided by the sum of the basal area of fir plus the basal area of pine) in the historical (1923) timber survey data. For tree density data, we analyzed all size classes pooled, as well as small (15.2 to

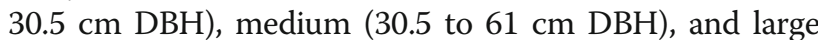
( $>61 \mathrm{~cm} \mathrm{DBH)} \mathrm{size} \mathrm{classes.} \mathrm{For} \mathrm{each} \mathrm{response} \mathrm{variable,} \mathrm{we}$ determined the set of predictor environmental variables that had the lowest AIC score, using exhaustive screening of all combinations of linear models implemented in the $\mathrm{R}$ package glmulti (Calcagno and Mazancourt 2010). Data for the small-tree size class were strongly right skewed, and these data were log-transformed prior to model selection.

Using the best-fit model, we interpreted the results using a regression tree analysis that implements recursive partitioning to identify important thresholds in the continuous predictor variables associated with the different mean values of the response variable. The recursive partitioning was implemented using the rpart package in $\mathrm{R}$ (Therneau et al. 2010), using the best model structure from the automated model selection, an ANOVA method for splitting variables, and a complexity parameter of 0.02 (for which the model $\mathrm{R}^{2}$ must increase by 0.02 at each split that is implemented in order for a split to be accepted). For the FPR response variable, we used a complexity parameter of 0.025 in order to avoid an overly complex regression tree.

To compare forest structure within similar environmental parameters in 1923 and 2001 to 2010, we used the breakpoints identified by the regression tree analysis, and applied them to the modern FIA data. We then calculated mean values for each forest structure variable within that environmental space. Finally, we estimated historical tree density at a landscape scale by using the best-fit model of historical density (Additional file 1: Table S1), and predicting values for each $270 \mathrm{~m}$ pixel when every climatic and topographic variable included in the best-fit model was within the range of that variable for which we had historical density data, to avoid extrapolating beyond the range of the sampled environmental space. Because the model fits were linear, some combinations of environmental variables at the warmer, drier end of the regional gradient that 
were poorly represented in our historical sample predicted historical tree densities below zero; we excluded these negative predictions from our visual depictions of landscape-scale densities.

\section{Results}

Tree density in 1923 was strongly influenced by three variables in the regression tree analysis: mean annual precipitation, mean 1 April snowpack, and mean annual climatic water deficit (Fig. 2a). Precipitation was the primary driver of density, with drier sites averaging less than $1299 \mathrm{~mm}$ of precipitation annually having average tree densities of 102 trees $\mathrm{ha}^{-1}$ (for all trees $>15.2 \mathrm{~cm} \mathrm{DBH}$ ). At sites wetter than $1299 \mathrm{~mm}$, density remained low $\left(\sim 98\right.$ trees $\left.\mathrm{ha}^{-1}\right)$ when snowpack was less than $378 \mathrm{~mm}$ and mean annual water deficit was greater than $587 \mathrm{~mm}$ (i.e., rain-dominated sites with poor water storage capacity, high evaporative demand, or both). Density was especially high in rain-dominated regions that had low climatic water deficit (Fig. 2a; Additional file 1: Table S1). Trends in small-tree density
(Additional file 1: Figure S2a) and medium-tree density (Additional file 1: Figure S3a) largely mirrored trends in total tree density, with denser sites associated with higher precipitation, lower water deficit, lower snowpack, and, in the case of medium-sized trees, northeasterly aspects. Large-tree density in the historical dataset, however, was most strongly influenced by mean June climatic water deficit and slope, with high June water deficit associated with low densities of large trees, and shallow slopes with lower June water deficit associated with the highest densities of large trees (Fig. 3a).

The modern FIA data indicated strong increases in tree density in the small and medium size classes (Table 1), and decreases in the largest size classes, particularly in trees $>91 \mathrm{~cm}$ DBH. In terms of environmental space, increases in density were fairly high across all conditions (Fig. 2b), but small-tree infilling was particularly pronounced in high-precipitation, rain-dominated areas in which pre fire-suppression or pre harvesting tree densities also tended to be higher (Additional file 1: Figure S2b). The loss of large trees was most pronounced in environments

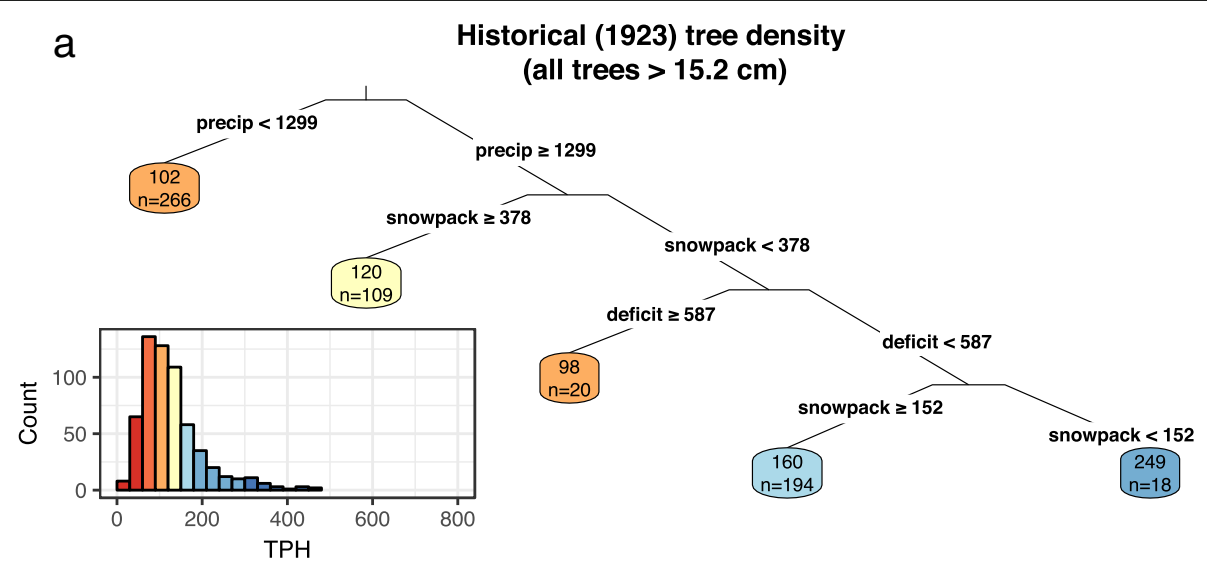

b

Modern (2001-2010) tree density

(all trees $>15.2 \mathrm{~cm}$ )

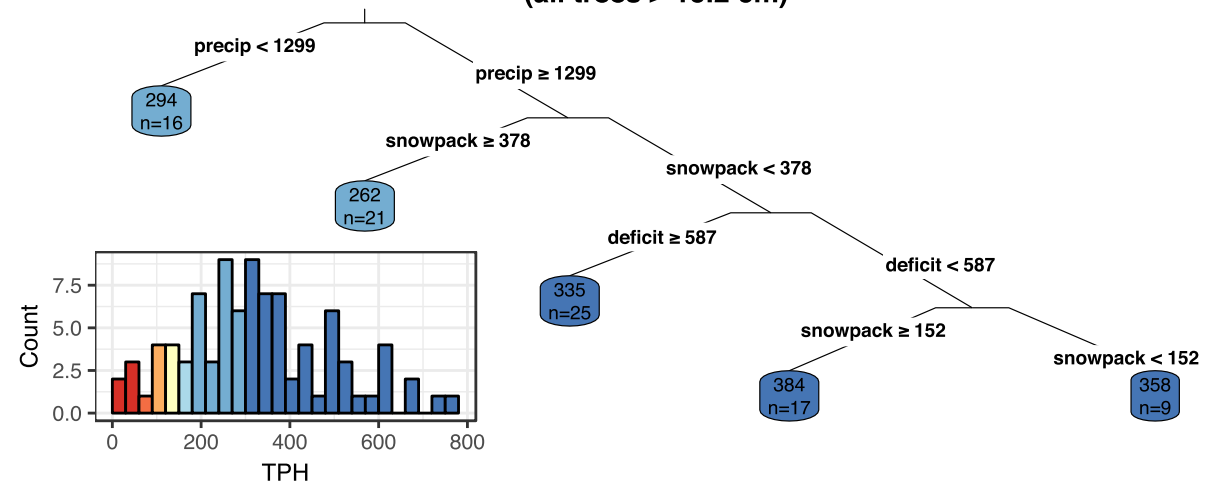

Fig. 2 Regression tree analysis of tree density $\left(\mathrm{TPH}\right.$; trees $\left.\mathrm{ha}^{-1}\right)$ for all trees $(>15.2 \mathrm{~cm} \mathrm{DBH})$ in (a) historical and (b) modern datasets. Inset histograms show distribution of density data, with bin colors in histograms corresponding to box colors in regression trees. Explanatory variables were selected from the best-fit model (Additional file 1: Table S1, model 4), and included mean June climatic water deficit (mm; deficit), mean annual precipitation (mm; precip), and mean 1 April snowpack depth (mm; snowpack) 
a

Historical (1923) tree density

(large trees $>61 \mathrm{~cm}$ )

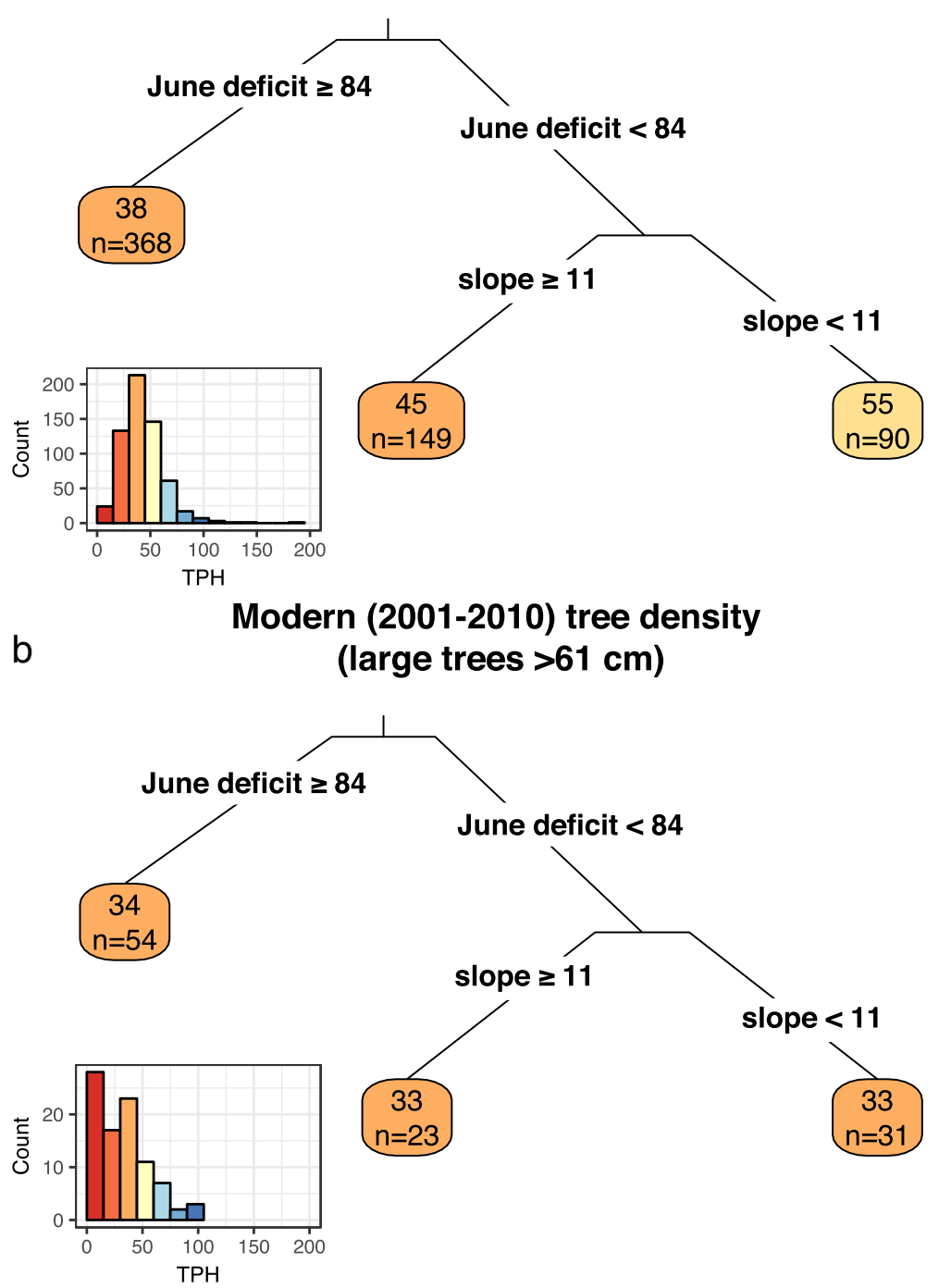

Fig. 3 Regression tree results for tree density (TPH; trees ha ${ }^{-1}$ ) for large trees (>61 cm DBH) in (a) historical and (b) modern datasets. Inset histograms show distribution of density data, with bin colors in histograms corresponding to box colors in regression trees. Explanatory variables were selected from the best-fit model (Additional file 1: Table S1, model 4), and included mean June climatic water deficit (mm; deficit) and mean slope (degrees)

with relatively low summer water deficit and shallow slopes, which is where the highest large tree densities were observed historically (Fig. 3b).

Environmental settings generally had a weaker signal on historical basal area compared to tree density (Fig. 4). This was at least partially due to the relatively narrow range in average basal area within the study area, which was generally between 40 and $50 \mathrm{~m}^{2} \mathrm{ha}^{-1}$, with little change over time (Table 1, Fig. 4). The environmental correlation trends for basal area were qualitatively similar to the trends for tree density, with particularly high basal area associated with northeasterly aspects, shallow slopes, low water deficit, and rain-dominated locations (Fig. 4a; Additional file 1:
Table S1). There were few plots in the modern dataset that met these conditions (Fig. 4b), so a comparison of basal area over time should be treated cautiously, but there does not appear to be strong evidence of an increase in basal area at the landscape scale.

Elevation, aspect, precipitation, and annual water deficit were the strongest drivers of the historical FPR on this landscape (Fig. 5a; Additional file 1: Table S1). Higher-elevation sites were strongly fir dominated, with many plots in this group dominated by red fir. At lower elevations, in more mixed-conifer forest types, the FPR skewed towards pines on southwesterly aspects, especially when precipitation was low, and on northeasterly 
Table 1 Summary of forest structure and environmental data from 1923 compared to 2001-2010. The smaller size classes (15 to 30 and 30 to $60 \mathrm{~cm} \mathrm{DBH}$ ) were adjusted from one third of the plots (those sampled in 1936) to bring the density down to estimated 1923 levels, as described in Methods. The environmental variables were averaged across all historical sample transects and FIA plots (2001-2010) using long-term average values from 1981 to 2010

\begin{tabular}{lcc}
\hline Forest structure and data & 1923 & 2001-2010 \\
\hline Trees per hectare 15 to $30 \mathrm{~cm} \mathrm{DBH}$ & 45.1 & 180.2 \\
Trees per hectare 30 to $60 \mathrm{~cm} \mathrm{DBH}$ & 40.4 & 113.1 \\
Trees per hectare 60 to $91 \mathrm{~cm} \mathrm{DBH}$ & 20.5 & 24.7 \\
Trees per hectare $>91 \mathrm{~cm}$ & 22.0 & 8.7 \\
Total trees per hectare & 128.0 & 326.7 \\
Total basal area $\left(\mathrm{m}^{2}\right.$ ha $^{-1}$ ) & 43.1 & 42.1 \\
Mean Abies:Pinus ratio & 0.6 & 0.5 \\
Mean elevation (m) & 1840.8 & 1740.0 \\
Mean annual precipitation $(\mathrm{mm})$ & 1402.8 & 1427.0 \\
Mean annual temperature $\left({ }^{\circ} \mathrm{C}\right)$ & 15.4 & 16.3 \\
\hline
\end{tabular}

aspects where deficit was high (due primarily to poor soil water holding capacity). In these areas, there was a shift towards fir dominance over time (Fig. 5b).

Based on our best-fit model of total tree density (>15 cm DBH; Additional file 1: Table S1), there was considerable variation in historical tree density across the landscape (Fig. 6). While predicted densities are likely overestimates at the extreme upper end and underestimates at the extreme lower end of the predicted density range, there were clearly areas on the landscape that were more dense than others even under a more active fire regime, due largely to climate variation within the mixed-conifer zone.

\section{Discussion}

Changes to fir-dominated $\mathrm{MC}$ forests in the northern Sierra Nevada were more subtle when compared to those in pine-dominated areas in the central and southern Sierra Nevada (Stephens et al. 2015; Collins et al. 2017). The most profound changes in this study included large increases in the density of small- to medium-sized trees and decreases in large-tree density (Table 1). The loss of large trees was most pronounced in environments in which large tree density had previously been highest in the historical surveys, which was on shallow slopes and in areas with lower June water deficit. Increases in tree density were fairly high across all conditions (Fig. 2b), but small-tree infilling was particularly pronounced in high-precipitation, rain-dominated areas where pre fire-suppression tree densities also tended to be larger. With a lower tree diameter limit of $15 \mathrm{~cm}$ in the historical data, we cannot fully characterize the forest structure of these areas.

The loss of the largest trees was also detected in pine-dominated mixed conifer forests in the central Sierra Nevada (Collins et al. 2017). These decreases were evident in areas managed by the US Forest Service (USFS), but not in areas managed by the US National Park Service. The explanation by Collins et al. (2017) for this difference in large-tree density was attributed to past timberharvesting practices, which primarily occurred on USFS lands. The same explanation likely applies in our study area, which is mostly on USFS land with some private lands (Fig. 1). Further support for this explanation is provided by the fact that large-tree losses were pronounced on gentler slopes, where logging equipment had better access for tree removal. Lastly, a pattern of greater large-tree reductions in areas where large tree density was higher to begin with matches logically with an early harvesting pattern that, for greater efficiency, would focus on areas with higher timber volume. Possibly higher infilling of trees in the more productive areas, due to fire suppression, could also have produced increased large-tree mortality from drought, bark beetles, or both in the contemporary landscape.

An important implication of the losses of large trees is the habitat needs of the California spotted owl (Strix occidentalis occidentalis; $\mathrm{CSO}$ ). The most commonly reported forest habitat feature for successful CSO nesting habitat is forest canopy cover $>70 \%$ (North et al. 2000), which has recently been suggested to be limiting to owl populations in several areas (Tempel et al. 2014; Tempel et al. 2015). A study that examined the sustainablity of this habitat type found that, within the next 75 years, the cumulative amount of nesting habitat burned by wildfires at high and moderate severity will exceed the total existing habitat in the Sierra Nevada (Stephens et al. 2016), raising significant concerns for this species (Jones et al. 2016). A recent study, however, found that total canopy cover is not as important to the CSO as the proportional cover in tall trees (North et al. 2017). Furthermore, owls were found to avoid areas with cover in the 2 to $16 \mathrm{~m}$ height strata. The significant long-term reduction of large trees and coincident increase in small- to mid-sized trees in our two study areas is evidence of a major structural shift that likely reduced preferred nesting and roosting habitat for CSO. Long-term plans to recruit large trees could possibly be a focus of management activities to improve CSO habitat in fir-dominated MC forests. Management could also target the removal of smaller trees that are in surplus in the current landscape to improve CSO habitat (North et al. 2017).

Similar to our results, Dolanc et al. (2014b) also found a reduction in the number of large trees from a comparison of recent data to that collected in the 1930s Vegetation Type Mapping (VTM; Wieslander 1935) project. 


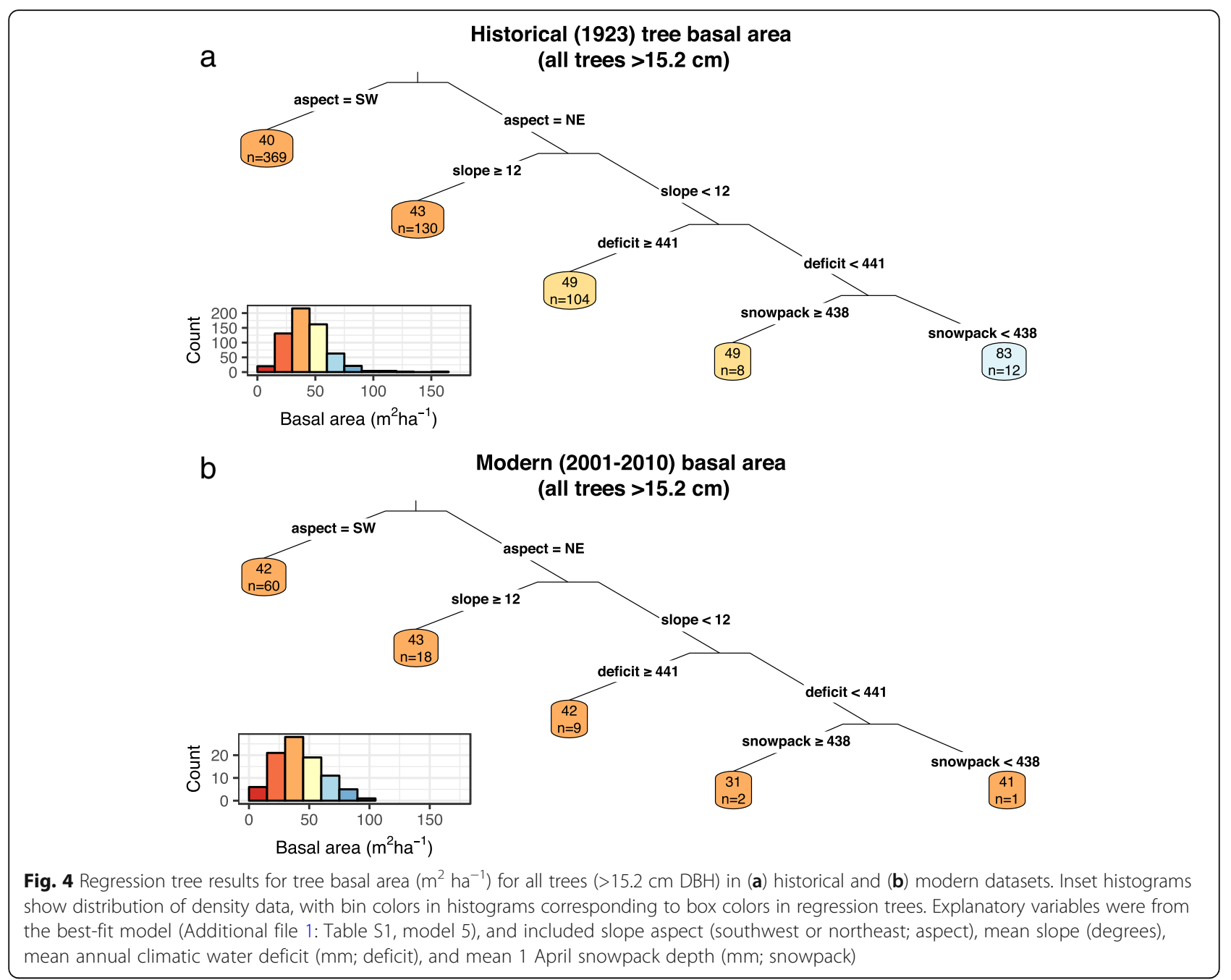

For large trees, densities were significantly lower in FIA plots for 7 of the 10 species analyzed, ranging from 26 to $40 \%$ lower than VTM levels. One interesting result from their study was that tree density in plots that burned twice were not statistically different than VTM levels, demonstrating the capacity of fire to produce historical conditions (Collins et al. 2011). Increasing density of small trees in higher elevations could be climatically driven (Dolanc et al. 2014b).

Our study found little difference in historical basal area between environmental settings in fir-dominated MC forests when compared with the variability observed in historical tree density (Fig. 4). Average basal area within the study area varied from 40 to $50 \mathrm{~m}^{2} \mathrm{ha}^{-1}$ across different topographic and climatic conditions, according to our regression tree analysis, with little change over time. Elevation, aspect, precipitation, and annual water deficit were the primary drivers of the historical species composition on this landscape (Fig. 5a). Higher-elevation sites were strongly fir-dominated, with many transects in this group dominated by red fir. At lower elevations, in more mixed-conifer forest types, the species composition skewed towards pines on southwesterly aspects, especially when precipitation was low, and on northeasterly aspects where water deficit was high; other studies have found pine preferences in similar climatic and topographic settings (Fites-Kaufman et al. 2007; Lydersen and North 2012).

Currently, basal area change relative to historical conditions is influenced in part by fire suppression, which would tend to lead to steady increases up to a given site's carrying capacity (Knapp et al. 2013; Levine et al. 2016). However, periodic harvesting would be expected to reduce basal area, causing it to fluctuate within a density management zone over time. Our inference that past harvesting practices were the likely cause of large-tree reductions, coupled with the fact that current basal areas are similar to pre fire-suppression levels, suggests that harvesting, combined with fire exclusion, has considerably increased tree densities compared to past conditions. The fact that large trees declined, while basal area has been maintained, indicates that structure has 

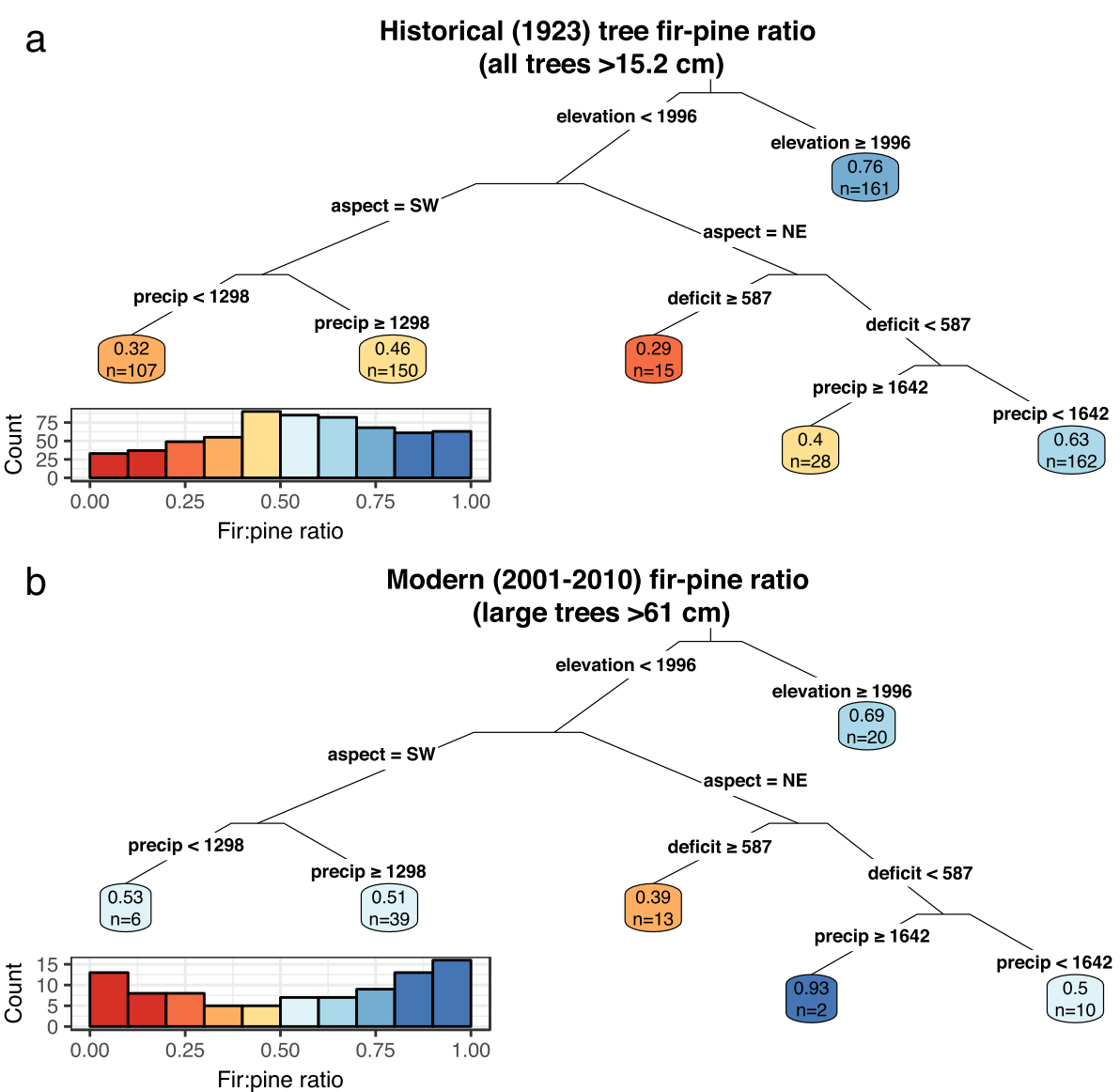

Fig. 5 Regression tree results for fir-pine ratio (FPR) for all trees (>15.2 cm DBH) in (a) historical and (b) modern datasets. Inset histograms show distribution of density data, with bin colors in histograms corresponding to box colors in regression trees. Smaller FPR values indicate dominance by pine species; larger values indicate fir dominance. Explanatory variables were selected from the best-fit model (Additional file 1: Table S1, model 6), and included elevation (m), slope aspect (southwest or northeast; aspect), mean annual precipitation (mm; precip), and mean annual climatic water deficit ( $m m$; deficit)

deviated significantly. Current harvesting practices that have restoration as an objective could focus on large-tree retention while reducing basal area in smaller and medium size classes and lowering surface fuels. Compared to lower-elevation pine-dominated $\mathrm{MC}$ forests, higher productivity fir-dominated $\mathrm{MC}$ forests could be managed within a fluctuating density range that is generally higher. For example, Eitzel et al. (2013) found that basal area in nearby forests that had not been disturbed (but had fire suppression) in the last century averaged $62 \mathrm{~m}^{2} \mathrm{ha}^{-1}$ and was still increasing, suggesting that functioning fire regimes reduced maximum basal area in these forests.

The roughly equal ratio of Abies and Pinus species that we found in both historical and contemporary forests (Table 1) is also relevant for restoration practices in this forest type. Unlike in pine-dominated MC forests, preferential removal of Abies species may not align with the objective of restoring species composition. Maintaining adequate regeneration of all species, especially Pinus species, will eventually require higher- intensity disturbances, at least at the local scale (York et al. 2011).

While we detected some changes in fir-dominated MC forests, they were far less pronounced than those found in pine-dominated areas in other portions of the Sierra Nevada that also used data from early intensive inventories (Stephens et al. 2015; Collins et al. 2017). Historical basal area in the most productive areas of MC forests $\left(41.8 \mathrm{~m}^{2} \mathrm{ha}^{-1}\right)$ in the southern Sierra Nevada was similar to what we found in this work, and tended to have greater fir dominance than the rest of the landscape. But in the areas classified as having average mixed-conifer conditions in the southern Sierra Nevada, basal area was much less (25 to $28 \mathrm{~m}^{2} \mathrm{ha}^{-1}$; Stephens et al. 2015). Similar to this study, overall southern Sierra Nevada MC basal area in 1911 was similar to contemporary conditions (29.5 versus $30.8 \mathrm{~m}^{2} \mathrm{ha}^{-1}$, respectively), but still lower than what was found at this study (Table 1). In contrast, pine-dominated areas in the southern Sierra Nevada underwent greater change and had significantly higher basal area in the 


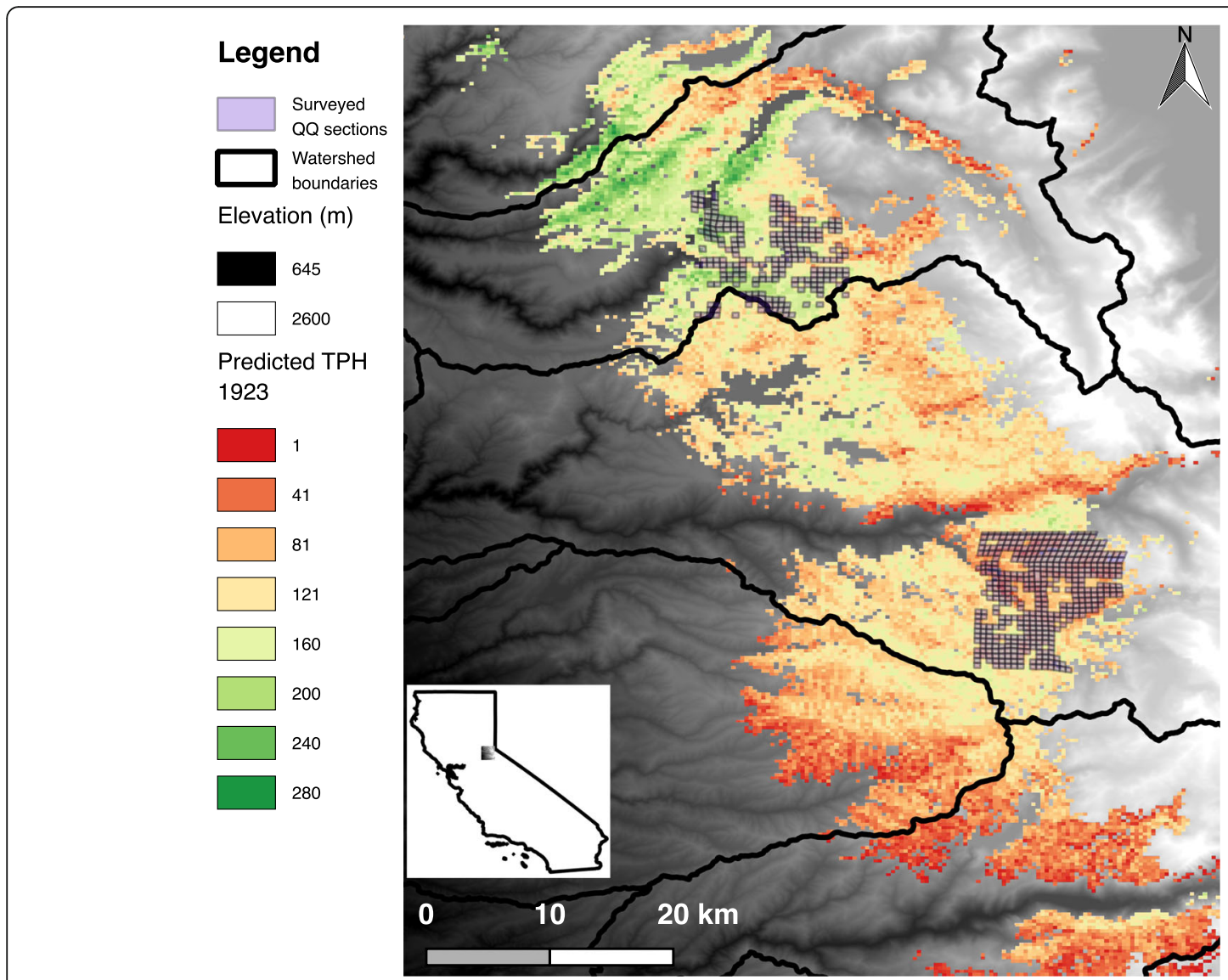

Fig. 6 Model prediction of landscape variation in tree density (TPH; all trees $>15.2 \mathrm{~cm} \mathrm{DBH)}$ in 1923. Predictions were based on the best-fit model for tree density (Additional file 1: Table S1) using the historical dataset; predictor variables were climatic water deficit, actual evapotranspiration, 1 April snowpack, mean annual high temperature, mean annual precipitation, slope, and aspect. Predictions were only made in geographic space within the range of each of the predictor variables given the historical dataset. Predicted values were truncated at $1 \mathrm{TPH}$ to exclude negative predicted values. Prediction resolution is $270 \mathrm{~m}$. Study area shown in inset figure. Watershed boundaries are as in Fig. 1

contemporary period versus the historical period (15.6 versus $11.2 \mathrm{~m}^{2} \mathrm{ha}^{-1}$, respectively).

Differences in the changes in structure in pine and fir-dominated $\mathrm{MC}$ forests may be an indication of different potential drivers of forest dynamics (i.e., fire was the dominant driver in pine-dominated forests, which kept stands relatively open and limited density well below site capacity; Show and Kotok 1924). As a result, it is possible that the expression of the biophysical environment (soil type, topography, local climate) was more muted in pine-dominated areas. In fir-dominated areas, however, the biophysical environment may have had a more pronounced influence on historical forest structure. The northern range of our study area was notable for its relatively high tree densities (Fig. 6); this area is noteworthy for having high mean annual precipitation relative to the southern portion of our study region (1619 compared to $1283 \mathrm{~mm}$ ). This area also tends to have higher actual evapotranspiration (431 mm compared to $401 \mathrm{~mm}$, influenced in part by deep soils) and much lower average 1 April snowpack depth (296 compared to $354 \mathrm{~mm}$ ) than higher elevations in our study, where densities were lower. This region represents a climatic "sweet-spot," where forests are not limited by moisture stress as at lower elevations, or by cold temperatures and shorter growing seasons as at higher elevations, where snow-dominated precipitation regimes may have higher precipitation but that water is not available due to temperature limitation and rapid draining of the soil profile during spring and summer snowmelt (Barbour et al. 1991).

The historical structure that we observed in these optimal climatic areas was likely influenced by fire as well, but faster tree growth in these regions may have meant trees were able to escape moderate-interval fire cycles of 20 to $30 \mathrm{yr}$ or, in some instances, may have created fire-resistant mesic microclimates ( $\mathrm{Ma}$ et al. 2010). It is likely not a coincidence that the regions we identified as having higher historical densities (Fig. 6) coincide both with areas used in modern times for private commercial timber harvesting and with areas on USFS lands known to have persistent populations of CSO, some of which 
have been negatively impacted by recent large patches of high-severity fire (Jones et al. 2016).

One important artifact of this work is the scale at which the 1923 data were recorded such that any fine-scale patterning cannot be discerned (Collins et al. 2015). The majority of the variability in structure in pine-dominated $\mathrm{MC}$ forests has been observed at spatial scales smaller than 0.4 ha (Larson and Churchill 2012; Lydersen et al. 2013; Fry et al. 2014), and topographic characteristics that influence forest structure may also be observed at a smaller scale (Lydersen and North 2012). This fine-scale patchiness, and the scale at which topography affects forest patterns, are important characteristics that warrant further investigation.

\section{Conclusion}

We detected some changes in fir-dominated MC forests but they were less pronounced than those found in pine-dominated MC forests in the Sierra Nevada (Stephens et al. 2015; Collins et al. 2017). However, even these historically denser areas have still been impacted by fire suppression and logging. The loss of large trees may have been the most important finding from this work and this change was found to be most pronounced in environments in which large-tree density had previously been highest (Fig. 3b). The loss of large trees could impact the habitat quality of the CSO, a species of concern in the Sierra Nevada. Management activities such as thinning and prescribed fire could be used to accelerate the development of large trees, and when this is combined with the removal of small to moderate sized trees and a reduction of surface fuels, it could produce more sustainable CSO habitat (Stephens et al. 2016). Even with proactive strategies to recruit large trees, however, it will take many decades for large trees to reach historical densities. Without management, severe wildfires are more likely and may set back large-tree recruitment efforts even more (Lydersen et al. 2017).

Our results combined with previous work in pinedominated MC forests in the Sierra Nevada (Stephens et al. 2015; Collins et al. 2017) indicate that restoration plans should be different depending on the type of mixed-conifer forest encountered. Whereas low tree densities and basal areas produced open-stand conditions in the pine-dominated regions of this forest type, other areas with longer growing seasons, higher water availability, and a greater dominance of fir species were more dense and likely important habit for late seral species such as the CSO. Working to develop forest restoration and adaptation plans to account for these differences is likely a key way forward.

\section{Additional file}

Additional file 1: Table S1. Model results for the set of historical forest structure response variables. Figure $\mathbf{S 1}$. Mean trees per hectare, by size class, for the five smallest size classes, in 1923 and 1936. Figure S2. Regression tree results for small-tree density (TPH $=$ trees ha ${ }^{-1}$ ) for trees 15.2 to $30.5 \mathrm{~cm}$ $\mathrm{DBH}$ in (a) historical and (b) modern datasets. Figure S3. Regression tree results for medium tree density $\left(\mathrm{TPH}=\right.$ trees ha $^{-1}$ ) for trees 30.5 to $61 \mathrm{~cm}$ $\mathrm{DBH}$ in (a) historical and (b) modern datasets. (DOCX 312 kb)

\section{Acknowledgements}

We thank J. van Wagtendonk for asking S. Stephens to take on this project, and for his support during the project. We recognize the early work presented in Bouldin (2004).

\section{Funding}

This project was funded through a grant from Yosemite National Park to S. Stephens at UC Berkeley.

\section{Availability of data and materials}

Contact author.

\section{Authors' contributions}

SLS, JTS, BMC, JML, and RAY all conceived of this study. JTS and JML did the data analysis. SLS, JTS, BMC, JML, and RAY contributed to the writing of the paper. All authors read and approved the final manuscript.

\section{Ethics approval and consent to participate}

Not applicable.

\section{Consent for publication}

Data used in this paper were provided to S. Stephens by the US National Park Service as part of a research study investigating historic forest structure in the Sierra Nevada.

\section{Competing interests}

The authors declare that they have no competing interests.

\section{Publisher's Note}

Springer Nature remains neutral with regard to jurisdictional claims in published maps and institutional affiliations.

\section{Author details}

${ }^{1}$ Department of Environmental Science, Policy, and Management, Ecosystem Sciences Division, University of California, 130 Mulford Hall, Berkeley, California 94720-3114, USA. ²University of California Center for Fire Research and Outreach, College of Natural Resources, 130, Mulford Hall, Berkeley, California 94720-3114, USA.

Received: 16 May 2018 Accepted: 14 September 2018

Published online: 20 December 2018

\section{References}

Agee, J.K., and C.N. Skinner. 2005. Basic principles of fuel reduction treatments. Forest Ecology and Management 211: 83-96.

Baker, W.L. 2014. Historical forest structure and fire in Sierran mixed-conifer forests reconstructed from general land office survey data. Ecosphere 5 (7): 79 https://doi.org/10.1890/ES14-00046.1.

Barbour, M.G., N.H. Berg, T.G. Kittel, and M.E. Kunz. 1991. Snowpack and the distribution of a major vegetation ecotone in the Sierra Nevada of California. Journal of Biogeography 18: 141-149 https://doi.org/10.2307/2845288.

Barbour, M.G., B. Pavlik, F. Drysdale, and S. Lindstrom. 1993. California's changing landscapes: Diversity and conservation of California vegetation. Sacramento: California Native Plant Society.

Beaty, R.M., and A.H. Taylor. 2001. Spatial and temporal variation of fire regimes in a mixed conifer forest landscape, southern cascades, California, USA. Journal of Biogeography 28: 955-966 https://doi.org/10.1046/j.1365-2699.2001.00591.x. Beaty, R.M., and A.H. Taylor. 2008. Fire history and the structure and dynamics of a mixed conifer forest landscape in the northern Sierra Nevada, Lake Tahoe Basin, California, 
USA. Forest Ecology and Management 255: 707-719 https://doi.org/10.1016/j. foreco.2007.09.044.

Beesley, D. 1996. Reconstructing the landscape: An environmental history, 1820-1960. In D.C. Erman, science team leader. Sierra Nevada ecosystem project: Final report to congress, volume ll, assessments and scientific basis for management options. University of California, centers for water and wildland resources, Davis, 1-24.

Biswell, H.H. 1989. Prescribed burning in California wildland vegetation management. Berkeley: University of California Press.

Bouldin, J.R. 2004. Forest conditions in fir-dominated forests in the Central Sierra Nevada in the early twentieth century, and relationship with pine-dominated forests. Yosemite National Park, California, USA: Unpublished report.

Calcagno, V., and C. de Mazancourt. 2010. GImulti: An R package for easy automated model selection with (generalized) linear models. Journal of Statistical Software 34: 1-29 https://doi.org/10.18637/jss.V034.112.

Collins, B.M., R.G. Everett, and S.L. Stephens. 2011. Impacts of fire exclusion and recent managed fire on forest structure in old growth Sierra Nevada mixedconifer forests. Ecosphere 2 (4): art51 https://doi.org/10.1890/ES11-00026.1.

Collins, B.M., D.L. Fry, J.M. Lydersen, R. Everett, and S.L. Stephens. 2017. Impacts of different land management histories on forest change. Ecological Applications 27: 2475-2486 https://doi.org/10.1002/eap.1622.

Collins, B.M., J.M. Lydersen, R.G. Everett, D.L. Fry, and S.L. Stephens. 2015. Novel characterization of landscape-level variability in historical vegetation structure. Ecological Applications 25: 1167-1174 https://doi.org/10.1890/141797.1.

Conard, S.G., and S.R. Radosevich. 1982. Post-fire succession in white fir (Abies concolor) vegetation of the northern Sierra Nevada. Madroño 29: 42-56.

Dolanc, C.R., H.D. Safford, S.Z. Dobroski, and J.H. Thorne. 2014a. Twentieth century shifts in abundance and composition of vegetation types of the Sierra Nevada, CA, US. Applied Vegetation Science 17: 442-455 https://doi.org/10. 1111 /avsc.12079

Dolanc, C.R., H.D. Safford, J.H. Thorne, and S.Z. Dobrowski. 2014b. Changing forest structure across the landscape of the Sierra Nevada, CA, USA, since the 1930s Ecosphere. 5 (8): 101 https://doi.org/10.1890/ES14-00103.1

Easterday, K., P. McIntyre, and M. Kelly. 2018. Land ownership and 20th century changes to forest structure in California. Forest Ecology and Management 422: 137-146 https://doi.org/10.1016/j.foreco.2018.04.012

Eitzel, M., J. Battles, R. York, J. Knape, and P. De Valpine. 2013. Estimating tree growth from complex forest monitoring data. Ecological Applications 23: 1288-1296 https://doi.org/10.1890/12-0504.1.

Fites-Kaufman, J., P.W. Rundel, N.L. Stephenson, and D.A. Weixelman. 2007. Montane and subalpine vegetation of the Sierra Nevada and Cascade ranges. In Terrestrial vegetation of California, ed. M.G. Barbour and J. Major, 456-501. Berkeley: University of California Press.

Flint, L.E., A.L. Flint, J.H. Thorne, and R. Boynton. 2013. Fine-scale hydrologic modeling for regional landscape applications: The California Basin characterization model development and performance. Ecology Process 2: 1$21 \mathrm{https}: / / \mathrm{doi} .0 \mathrm{rg} / 10.1186 / 2192-1709-2-25$.

Fry, D.L., S.L. Stephens, B.M. Collins, M.P. North, E. Franco-Vizcaino, and S.J. Gill. 2014. Contrasting spatial patterns in active-fire and fire-suppressed mediterranean climate old-growth mixed conifer forests. PLoS One 9 (2): e88985 https://doi.org/10.1371/journal.pone.0088985.

Hagmann, K.R., J.T. Stevens, J.M. Lydersen, B.M. Collins, J.J. Battles, P.F. Hessburg, C.R. Levine, A.G. Merschel, S.L. Stephens, A.H. Taylor, J.F. Franklin, D.L. Johnson, and K. N. Johnson. 2018. Improving the use of early timber inventories in reconstructing historical dry forests and fire in the western United States: Comment. Ecosphere 9: e02232 https://doi.org/10.1002/ecs2.2232.

Hessburg PF, Spies TA, Perry DA, Skinner CN, Taylor AH, Brown PM, Stephens SL, Larson AJ, Churchill DJ, Povak NA, Singleton PH, McComb B, Zielinski WJ, Collins BM, Salter RB, Keane JJ, Franklin JF, Riegel G (2016) Tamm review: Management of mixed-severity fire regime forests in Oregon, Washington, and northern California. Forest Ecology and Management 366:221-250 https://doi.org/10.1016/j.foreco. 2016.01.034

Jones, G.M., R.J. Gutiérrez, D.J. Tempel, S.A. Whitmore, W.J. Berigan, and M.Z. Peery. 2016. Megafires: An emerging threat to old-forest species. Frontiers in Ecology and the Environment 14: 300-306 https://doi.org/10.1002/fee.1298

Knapp, E.E., C.N. Skinner, M.P. North, and B.L. Estes. 2013. Long-term overstory and understory change following logging and fire exclusion in a Sierra Nevada mixed-conifer forest. Forest Ecology and Management 310: 903-914 https://doi.org/10.1016/j.foreco.2013.09.041.

Larson, A.J., and D.C. Churchill. 2012. Tree spatial patterns in fire-frequent forests of western North America, including mechanisms of pattern formation and implications for designing fuel reduction and restoration treatments. Forest Ecology and Management 267: 74-92 https://doi.org/10. 1016/j.foreco.2011.11.038

Levine, C.R., C.V. Cogbill, B.M. Collins, A.J. Larson, J.A. Lutz, M.P. North, C.M. Restaino, H.D. Safford, S.L. Stephens, and J.J. Battles. 2017. Evaluating a new method for reconstructing forest conditions from general land office survey records. Ecological Applications 27: 1498-1513 https://doi.org/10.1002/eap.1543.

Levine, C.R., F. Krivak-Tetley, N.S. van Doorn, J.S. Ansley, and J. Battles. 2016. Longterm demographic trends in a fire-suppressed mixed conifer forest. Canadian Journal of Forest Research 46: 745-752 https://doi.org/10.1139/cjfr-2015-0406.

Lydersen, J., and M. North. 2012. Topographic variation in structure of mixedconifer forests under an active-fire regime. Ecosystems 15: 1134-1146 https:// doi.org/10.1007/s10021-012-9573-8.

Lydersen, J.M., B.M. Collins, M.L. Brooks, J.R. Matchett, K.L. Shive, N.A. Povak, V.R. Kane, and D.F. Smith. 2017. Evidence of fuels management and fire weather influencing fire severity in an extreme fire event. Ecological Applications 27: 2013-2030 https://doi.org/10.1002/eap.1586.

Lydersen, J.M., M.P. North, E.E. Knapp, and B.M. Collins. 2013. Quantifying spatial patterns of tree groups and gaps in mixed-conifer forests: Reference conditions and long-term changes following fire suppression and logging. Forest Ecology and Management 304: 370-382 https://doi.org/10.1016/j. foreco.2013.05.023.

Ma, S., A. Concilio, B. Oakley, M. North, and J. Chen. 2010. Spatial variability in microclimate in a mixed-conifer forest before and after thinning and burning treatments. Forest Ecology and Management 259: 904-915 https://doi.org/10. 1016/j.foreco.2009.11.030.

Meyer, M.D., and M.P. North. 2018. Natural range of variation of red fir and subalpine forests in the Sierra Nevada bioregion. US Department of Agriculture, Forest Service general technical report PSW-GTR-XXX. Albany: Pacific Southwest Research Station [In press].

Millar, C.I., N.L. Stephenson, and S.L. Stephens. 2007. Climate change and forests of the future: Managing in the face of uncertainty. Ecological Applications 17: 2145-2151 https://doi.org/10.1890/06-1715.1.

North, M., G. Steger, R. Denton, G. Eberlein, T. Munton, and K. Johnson. 2000. Association of weather and nest-site structure with reproductive success in California spotted owls. Journal of Wildlife Management 64: 797-807 https:// doi.org/10.2307/3802750.

North, M.P., J.T. Kane, V.R. Kane, G.P. Asner, W. Berigan, D.J. Churchill, S. Conway, R. J. Gutiérrez, S. Jeronimo, J. Keane, A. Koltunov, T. Mark, M. Moskal, T. Munton, Z. Peery, C. Ramirez, R. Sollmann, A.M. White, and S. Whitmore. 2017. Cover of tall trees best predicts California spotted owl habitat. Forest Ecology and Management 405: 166-178 https://doi.org/10.1016/j.foreco.2017.09.019.

Parsons, D.J., and S.H. Debenedetti. 1979. Impact of fire suppression on a mixedconifer forest. Forest Ecology and Management 2: 21-33 https://doi.org/10. 1016/0378-1127(79)90034-3.

Perry, D.A., P.F. Hessburg, C.N. Skinner, T.A. Spies, S.L. Stephens, A.H. Taylor, J.F. Franklin, B. McComb, and G. Riegel. 2011. The ecology of mixed severity fire regimes in Washington, Oregon, and northern California. Forest Ecology and Management 262: 703-717 https://doi.org/10.1016/j.foreco.2011.05.004.

Polkinghorn, R.S. 1984. Pino Grande: Logging railroads of the Michigan-California lumber company. Glendale: Trans-Anglo Books.

Safford, H.D., and J.T. Stevens. 2017. Natural range of variation for yellow pine and mixedconifer forests in the Sierra Nevada, southern cascades, and Modoc and Inyo national forests, California, USA. Albany: US Department of Agriculture, Forest Service, General Technical Report PSWGTR-256, Pacific Southwest Research Station.

Show, S.B., and E.I. Kotok. 1924. The role of fire in the California pine forests. US Department of Agriculture Bulletin no. 1294. Washington, D.C.: Government Printing Office.

Stephens, S.L., and B.M. Collins. 2004. Fire regimes of mixed conifer forests in the northCentral Sierra Nevada at multiple spatial scales. Northwest Science 78: 12-23.

Stephens, S.L., J.M. Lydersen, B.M. Collins, D.L. Fry, and M.D. Meyer. 2015. Historical and current landscape-scale ponderosa pine and mixed-conifer forest structure in the southern Sierra Nevada. Ecosphere 6 (5): art 79 https://doi. org/10.1890/ES14-00379.1.

Stephens, S.L., C.I. Millar, and B.M. Collins. 2010. Operational approaches to managing forests of the future in Mediterranean regions within a context of changing climates. Environmental Research Letters 5: 024003 https://doi.org/ 10.1088/1748-9326/5/2/024003

Stephens, S.L., J.D. Miller, B.M. Collins, M.P. North, J.J. Keane, and S.L. Roberts. 2016. Wildfire impacts on California spotted owl nesting habitat in the Sierra Nevada. Ecosphere 7 (11): e01478 https://doi.org/10.1002/ecs2.1478. 
Stephens, S.L., J.J. Moghaddas, C. Ediminster, C.E. Fiedler, S. Hasse, M. Harrington, J.E. Keeley, J.D. Mclver, K. Metlen, C.N. Skinner, and A. Youngblood. 2009. Fire treatment effects on vegetation structure, fuels, and potential fire severity in western US forests. Ecological Applications 19: 305-320 https://doi.org/10. 1890/07-1755.1.

Sudworth, G. 1899. Photos by George Sudworth (photos $15951 a$ and 15959a). Berkeley: University of California, Bioscience and Natural Resources Library.

Taylor, A.H., and C.B. Halpern. 1991. The structure and dynamics of Abies magnifica forests in the southern Cascade Range, USA. Journal of Vegetation Science 2: 189-200 https://doi.org/10.2307/3235951.

Taylor, A.H., and M.N. Solem. 2001. Fire regimes and stand dynamics in an upper montane forest landscape in the southern cascades, Caribou wilderness, California. Journal Torrey Botanical Society 128: 350-361 https://doi.org/10. 2307/3088667

Tempel, D.J., R.J. Gutierrez, J.J. Battles, D.L. Fry, Y. Su, Q. Guo, M.J. Reetz, S.A. Whitmore, G.M. Jones, B.M. Collins, S.L. Stephens, M. Kelly, W.J. Berigan, and M.Z. Peery. 2015. Evaluating short- and long-term impacts of fuels treatments and simulated wildfire on an old-forest species. Ecosphere 6 (12): art261 https://doi.org/10.1890/ES15-00234.1.

Tempel, D.J., R.J. Gutiérrez, S.A. Whitmore, M.J. Reetz, R.E. Stoelting, WJ. Berigan, M.E. Seamans, and M.Z. Peery. 2014. Effects of forest management on California spotted owls: Implications for reducing wildfire risk in fire-prone forests. Ecological Applications 24: 2089-2106 https://doi.org/10.1890/13-2192.1.

Therneau, T.M, B. Atkinson, and B. Ripley. 2010. rpart: recursive partitioning. R package. <https://cran.r-project.org/web/packages/rpart/rpart.pdf>. Accessed 23 Sept 2018

Vankat, J.L., and J. Major. 1978. Vegetation changes in Sequoia National Park, California. Journal of Biogeography 5: 377-402 https://doi.org/10.2307/ 3038030.

Wieslander, A.E. 1935. A vegetation type map of California. Madroño 3 (3): 140-144. Woudenberg, S.W., B.L. Conkling, B.M. O'Connell, E.B. LaPoint, J.A. Turner, and K.L. Waddell. 2010. The Forest inventory and analysis database: Database description and users manual version 4.0 for phase 2. Fort Collins: US Department of Agriculture, Forest Service General Technical Report RMRSGTR-245, Rocky Mountain Research Station.

York, R.A., J.J. Battles, R.C. Wenk, and D. Saah. 2011. A gap-based approach for regenerating pine species and reducing surface fuels in multi-aged mixed conifer stands in the Sierra Nevada. California Forestry 85: 203-213.

\section{Submit your manuscript to a SpringerOpen ${ }^{\circ}$ journal and benefit from:}

- Convenient online submission

- Rigorous peer review

- Open access: articles freely available online

- High visibility within the field

- Retaining the copyright to your article

Submit your next manuscript at $\boldsymbol{\nabla}$ springeropen.com 